\title{
EU research chief to raise political profile
}

Paris. Edith Cresson, the former French prime minister who takes office next Monday as the European Union (EU)'s commissioner for research and education, said last week that Europe needs to negotiate more as a single bloc in areas of international scientific cooperation where the United States and Japan are already strong (see Nature 368, 385; 1994).

Outlining her policies for the first time at a three-hour hearing before the European Parliament, she claimed that such scientific cooperation should be the main element of EU foreign policy "next to trade".

As further evidence of her desire to focus attention on the need for European research to compete internationally, Cresson also argued that institutional procedures need to be reformed to counteract the tendency of individual member states to defend their own narrow interests in distributing the EU's research budget.

In particular, she proposed reducing the role of research programme committees from allocating resources to merely advising the commission on how this should be done. Such committees are made up of commission officials and national civil servants, a procedure that observers say actively encourages political horsetrading (see Nature 366, 7; 1993).

Overall, Cresson gave observers the impression that her term of office will bring a 'hands-on' and 'offensive' approach to European research. "We're giving her 8 out of 10 for dynamism", says one usually cynical official from the parliament's Energy, Research and Technology Committee.

Many feel that Cresson's political skills may help to push research up the EU's agenda. She has already endorsed the white paper on "competitiveness, growth and unemployment', by Jacques Delors, the outgoing commission president, which emphasized the importance of research and education to Europe's economic recovery.

Cresson told the parliament that closer linkage between research and education is one of her priorities. She also caused surprise by backing some of the parliament's long running demands - including the plans that the EU's four joint research centres should compete with others for funds (see Nature 366, 499; 1993).

Cresson's speech was high on good intentions, but it remains to be seen how successful she will be in translating talk into action. One contentious issue is her proposal to draw together more national research efforts into large European programmes.

Such a move would reflect the Maastricht Treaty's extension of the goals of EU-funded research from merely "strengthening the scientific and technological basis of European industry" to promoting cooperation on virtually any research considered valuable to Europe. Cresson points out that the treaty gives the EU a mandate to coordinate national research policies with those of the EU. But programmes involving some - but not necessarily all - member states will inevitably be controversial. To prevent individual member states feeling left out by such 'variable geometry', the commission will probably approve simultaneously a balanced portfolio of multilateral programmes (see Nature 371, 728; 1994).

Moreover, although Cresson proposed new joint development programmes in, for 㕸 example, AIDS research, environmental technol-

\section{IMAGE UNAVAILABLE FOR COPYRIGHT REASONS}

\section{Cresson: seeks to} cut committees' role. ogy, electric cars and educational applications of multimedia, it is not always clear that such research would be better carried out at the European level or through the commission.

Officials also say that the creation of such programmes is likely to face serious "technical, political and management" problems. To test the viability of the proposal, Cresson intends to use the FFr700 million (US\$130 million) held in reserve for the fourth Framework programme to launch several pilot programmes.

An incentive for national agencies (and their governments) to participate in such programmes is that financial pressures on national research budgets are making it increasingly necessary for member states to focus their resources on joint programmes. But many member states are reluctant to give up more power to the commission, says one official, in particular because they feel that the quality of EU programmes is lower than that of their own national programmes.
To help overcome this reluctance, the commission is now willing to share control of Europe-wide programmes with national agencies, he adds.

Indeed, Cresson is proposing that the planned European research programmes should be run not by the commission but by consortia of member states, using legal structures such as the Groupement Européen d'Intérêt Économique used, for example, by the Airbus consortium.

She argues that such programmes must meet the needs of European industry and the market. Indeed, details of such programmes could be proposed mainly by joint 'task forces' set up between the research directorate and the directorates for industry and telecommunications.

The shift in emphasis towards focused social and economic goals is underlined by the fact that the European Science and Technology Assembly - an advisory body mainly made up of scientists, which was recently created by Antonio Ruberti, Cresson's predecessor - seems unlikely to be given a major say in the new programmes.

One obstacle facing Cresson is that the conservative governments in office in most European countries would oppose the interventionist industrial policies that Cresson, as a socialist, strongly advocated when she was prime minister.

But with such conservative governments increasingly looking for ways of organizing research that will maximize its economic and social benefits, Cresson's proposals for more joint technology forecasting are likely to be welcomed. Germany, France and the United Kingdom, for example, have already agreed to compare the results of individual forecasting exercises. British officials add that the commission is already considering using 'foresight' exercises to determine the content of the fifth Framework programme, which will run from 1999 to 2003 .

Declan Butler

\section{Italy approves changes at space agency}

Munich. Italy's minister for research and universities, Stefano Podestá, has succeeded in his efforts to concentrate control of the Italian Space Agency (ASI) in the hands of a single administrator.

Following a decree approved by the caretaker government, ASI's science committee, its financial review board and its administration board have all been disbanded. Mario Calamia, the agency's director general, is expected to be appointed as the so-called amministratore unico in the near future, with broad-ranging powers to restructure the agency and suggest solutions to its financial problems.

A bid by Podestá last autumn to persuade the government to introduce the decree failed on the grounds that the changes were not sufficiently urgent. Subsequent efforts to have the changes approved as a bill by the Italian parliament backfired when both scientists and opposition politicians claimed that the changes were being introduced without proper consultation (see Nature 372, 719; 1994).

Shortly after the bill was introduced, the government coalition fell. As the bill's passage through parliament was certain to be delayed, Podestá successfully persuaded Silvio Berlusconi, prime minister of the caretaker government, to enact the original decree, and this has now been approved by the president, Oscar Luigi Scalfaro.
Alison Abbott 